\title{
THE MILLENNIALS LUXURY BRAND ENGAGEMENT ON SOCIAL MEDIA: A COMPARATIVE STUDY OF BRAZILIANS AND ITALIANS
}

\author{
Melissa Akemi Casagrande Yamawaki \& Gilberto Sarfati ${ }^{1}$ \\ Università Commerciale Luigi Bocconi, Milan, (Italy) \\ University of São Paulo - USP, São Paulo, (Brazil)
}

ARTICLE DETAILS
Article history:
Received: January 312018
Accepted june 82018
Available online November $22^{\text {th }} 2018$
Double Blind Review System
Scientifc Editor
Ilan Avrichir
Keywords:
Consumer Engagement
Luxury Brands
Social Media
Culture;
Millennials

\begin{abstract}
Over the last decades, social media has become one of the most popular online activity among consumers worldwide, leading companies to adapt and evolve their strategies in other to engage the consumer through new medias. Considering the online environment, the social media has a key participation when building consumer brand engagement. Consumers can develop three roles in this situation: consumer, contributor or creator of content. This empirical study aims to understand and compare the consumer brand engagement of millennials in luxury brands on social media between Brazil and Italy. The luxury brands chosen are Louis Vuitton, Chanel, and Prada and the social medias are Facebook, Twitter, YouTube and Instagram. The study used a quantitative research design, with a questionnaire survey based on COBRA framework and Hofstede's model. We collected 438 valid answers. The results suggest a relationship between culture and consumer brand engagement on luxury brands through social media among millennials from Brazil and Italy.
\end{abstract}

C 2018 Internext | ESPM. All rights reserved!

\section{INTRODUCTION}

Over the last years we have seen the growth of the social media (SM) phenomenon, which are technological platforms for individuals to connect, produce and share content online (Boyd \& Ellison, 2008). The first website recognizable as a SM was the Six Degree, created in 1997. By 1999, the first blogging websites started to boom and it is in use until today; during the early 2000s, socials like Myspace, Linkedln, Flickr, YouTube, Facebook and Twitter were created, leading to the current online environment. As a result of people's interaction in these platforms, SM became one of the most popular online activity among consumers worldwide (Li \& Bernoff, 2011; Kujur \& Singh, 2015) and are considered by some scholars as another dimension inside the marketing mix of a company (Cvijikj \& Michahelles, 2013).
Through SM consumers can criticize, compliment, rate and rank brands online: all of these options made consumers much more critical and aware of brandrelated events and incidents (Fournier \& Avery, 2011). Consequently, SM plays a central role in companies' marketing. SM activities are particularly important to millennials (adults born between 1980 and 1994, (Alsop, 2008; Sweeney, 2005)), as internet plays a central role in their daily habits and their lives are completely integrated into the tech world (Lenhard et al., 2010).

Millennials shoppers are three times more likely than other generations to use social media to learn about products, express their opinion online or to post photos about products; they also turn to friends, family and strangers on social for more information about the product or service they are interested in (Market Strategies, 2014).

\footnotetext{
${ }^{1}$ Corresponding author - Email: gilberto.sarfati@fgv.br
} 
This generation actively contributes, shares, likes, searches for and consume content online, mainly through social media platforms. These activities are related to what marketing theory calls consumer engagement, which can be described as an ongoing emotional, cognitive, and behavioral investment in specific brand interactions (Hollebeek, 2011).

In spite of several studies covering the relationship between brand engagement and SM (Kim \& Ko 2010; Kujur \& Singh, 2015, Schivinski, Christodoulides \& Dabrowski, 2016) little is known about how millennials engage with luxury brands specially in a cross-cultural context. This study, aims to understand how culture can influence the millennials consumer engagement on social media, targeting luxury brands in two Latin countries with high engagement with luxury: Brazil and Italy. The brands studied are Chanel, Louis Vuitton, and Prada and the social medias are Facebook, Instagram, YouTube and Twitter.

The study used a quantitative research design, with an online questionnaire survey in order to collect the responses. The survey was based on COBRA framework (Mutinga, Moorman \& Smit, 2011) that demonstrate the path of involvement with bandrelated content: a) consuming brand-related content; b) Contributing brand-related content and c) creating brand-related content and, Hofstede's (2001) culture model which describes culture difference among managers around 6 dimensions: power distance; uncertainty avoidance; individualism versus collectivism; masculinity versus femininity; indulgence and long term versus short term orientation.

Results shows that national culture affects millennials perceptions about luxury brands online. We found that Brazilians millennial luxury brand engagement is affected by digital influencers, while for Italians is less relevant. At the same time, if Brazilians millennials are able to consume luxury brands they are more willing than Italians to share content online about their own achievement. Finally, Brazilian millennials are less prone than Italians to be influenced by other peers online.

\section{LITERATURE REVIEW}

\section{Millennials and social media}

The most recent generation to reach adulthood is the Millennials, Generation Y or "Why", which are people born between 1980 and 1994. They present some unique characteristics: for the optimistic, such as Raines (2003), millennials are sociable, optimistic, talented, well-educated, collaborative, open-minded, influential, and achievement-oriented; however, for more pessimistic researches, millennials are stressed, anxious, unproductive, lazy, narcissistic, and prone to jump from job to job.

Regarding their daily habits, millennials have different patterns from the two past generations (Generation X, which are people born between the middle 1960s until 1980 and Baby Boomers, which is the generation born from 1946 to the middle 1960s): their internet usage is diverse, spending preferences are broader, and their shopping ways is also different (USC Dornsife, 2017). Millennials can also be called "Digital Natives" as it is the first one to have spent their entire lives in the digital environment. According to Lenhard et al. (2010), internet has a central role in millennials' lives and they exhibit a unique pattern of using it, being very diverse from the preceding generation (Killian et al., 2012). The creation of SM, bound with the unique interaction millennials have on it, developed the "participation economy" (Fromm \& Garton, 2013): as this generation is not willing to be passive consumers, they actively participate, create and co-create content online and have higher engagement and interaction with brands.

Millennials are highly influenced by social media in many ways (Martin \&Turley, 2004) and are affected by online reviews more than other generation (Smith, 2012). Some studies showed that millennials are the first generation to give a greater importance to online word of mouth (information shared on SM) than to traditional types of recommendations or advertising tools (Senecal \& Nantel, 2004; Smith, 2011). Thus, as Pate and Adam (2013) found out, millennials are more likely to acquire a product that was "liked" or recommended by their friends on SM and they perceive comments as more "transparent" and blogs "more objective". SM plays a fundamental role at millennials' consumer behavior. SM platforms has a greater impact mainly in two stages of the consumer funnel:

(1) Pre-purchase: as a source of information in order to make a purchase decision.

(2) Post-consumption: as it is used to share their experience of the product and the brand from which they had purchased (both positive and negatives experiences). 
The Millennials Luxury Brand Engagement on Social Media: A Comparative Study of Brazilians and Italians

\section{Consumer Brand Engagement}

Even though there is an increasingly amount of interest on this topic, research on consumers' engagement is still at a nascent stage (Schultz \& Peltier, 2013), thus empirically based studies are scarce. Regardless the stage of academic studies, consumer brand engagement (CBE) is emerging as a central topic when developing a brand strategy in businesses due to its importance when developing brand loyalty, trust, satisfaction, and commitment (Lujja \& Ozata, 2017). There are several definitions of CBE: the one used in this study is that CBE is as an ongoing emotional, cognitive, and behavioral investment in specific brand interactions (Hollebeek, 2011). Nonetheless, other scholars such as Bowden (2009) states that the CBE is as a psychological process that shapes the mechanisms by which customer relationship and loyalty forms for new customers as well as the mechanisms by which loyalty is maintained for repeat-purchase customers. As showed previously, many scholars have different definition, ranging from the creating deep connections with customers decision to the behavioral manifestation towards a brand, on Table 1 it is possible to observe the most important definitions developed so far.

Table 1 - Consumer Engagement Definitions

\begin{tabular}{|c|c|}
\hline Reference & Definition \\
\hline $\begin{array}{l}\text { Vivek, Beatry and Mogan } \\
\text { (2012: 133) }\end{array}$ & $\begin{array}{l}\text { Consumer Engagement is the intensity of an individual's participation } \\
\text { in and connection with an organization's offerings and or organizational } \\
\text { activities, which either the customer or the organization initiate. }\end{array}$ \\
\hline Brodie et al., (2011b:260) & $\begin{array}{l}\text { Consumer Engagement a psychological state that occurs by virtue of } \\
\text { interactive, co-creative customer experience with a focal agent/object } \\
\text { (e.g a brand) in focal service relationships }\end{array}$ \\
\hline Hollebeek (2011:790) & $\begin{array}{l}\text { Customer Brand Engagement refers to the level of a customer's } \\
\text { motivational, brand-related and context dependent state of mind } \\
\text { characterized by specific levels of cognitive, emotional, and behavioral } \\
\text { activity in brand interactions. }\end{array}$ \\
\hline Patterson et al., (2006a) & $\begin{array}{l}\text { Consumer Engagement is the level of a customer's physical, cognitive } \\
\text { and emotional presence in their relationship with a service } \\
\text { organization. }\end{array}$ \\
\hline Van Doorn et al. (2010:254) & $\begin{array}{l}\text { Customer Engagement refers to the behavioral manifestation from a } \\
\text { customer toward a brand or a firm, which goes beyond purchase } \\
\text { behavior. }\end{array}$ \\
\hline Forester Consulting (2008) & $\begin{array}{l}\text { Consumer Engagement refers to creating deep connections with } \\
\text { customers that drive purchase decisions, interaction, and in } \\
\text { participation over time. }\end{array}$ \\
\hline $\begin{array}{l}\text { Marketing Science Institute } \\
(2010: 4)\end{array}$ & $\begin{array}{l}\text { Consumer Engagement refers to customers' behavioral manifestation } \\
\text { towards a brand or a firm beyond purchase, which results from } \\
\text { motivational drivers including word-of-mouth activity, } \\
\text { recommendations, customer-to-customer interactions, blogging, } \\
\text { writing reviews and other similar activities. }\end{array}$ \\
\hline
\end{tabular}

Source: Lujja \& Ozata (2017)

Considering the definitions, it is logical to assume that in order to keep up with market changes and engage consumers, the brands have to reshape their marketing strategies and get into customers' lives, activating them both emotionally, physically, and cognitively, trying to establish with them a deep and authentic relationship, getting more intimate, private, and exclusive over time (Gambetti \& Graffigna, 2014). One of the pioneer studies in this field, developed by Hollebeek, Glynn and Brodie (2014), stated that CBE has three different stages, one antecedent the engagement, which they call it "involvement" with the brand. The engagement per se, which includes: (1) a cognitive process with the brand, which is related to what and when the consumers think about the brand and what stimulate their thoughts, (2) affection, which is the positive feeling related to the use of the brand and (3) activation, which is related to the level of usage of the brand related to others. The consequences of the CBE, according to the study, is the personal connection with the brand and the higher intent to use or re-purchase from the same brand.

\section{Consumer Brand Engagement on Social Media}

The invention of internet has changed the way marketing is done. The interest in brands on the internet had its start in the 1990s, when people started to use websites such as Yahoo and AOL to share their opinions about products (Kozinets, 2001). The internet has created and developed a new dimension of consumer involvement with brands in SM, becoming one of the most popular online activity among consumers worldwide (Li \& Bernoff, 2011; Kujur \& Singh, 2015), as social networking websites such as Facebook, Twitter, Instagram, and YouTube (platforms that allow people to share and create content about anything) have become increasingly central in consumers' lives, influencing thus their communication and buying habits (Schivinski, Christodoulides \& Dabrowski, 2016). Therefore, according to Kim and Ko (2010) and Kujur and Singh 
(2015), social media can have dramatic impact on a brand's reputation, as the main purpose of social media in the business context is to raise the level of involvement, interaction, and intimacy with the brand over time.

Regarding the interaction and communication through SM, there is a research by Zailskaite-Jakse and
Kuvykaite (2016) that display in a simple diagram how the personal traits of a person together with his motives are related to the communication in social media, then, how this communication can enhance the brand equity through awareness, associations, and loyalty. Also, the culture in this framework would be part of the antecedents, with personal traits and engagement motives.

Figure 1 - Model of communication in social media regarding brand equity

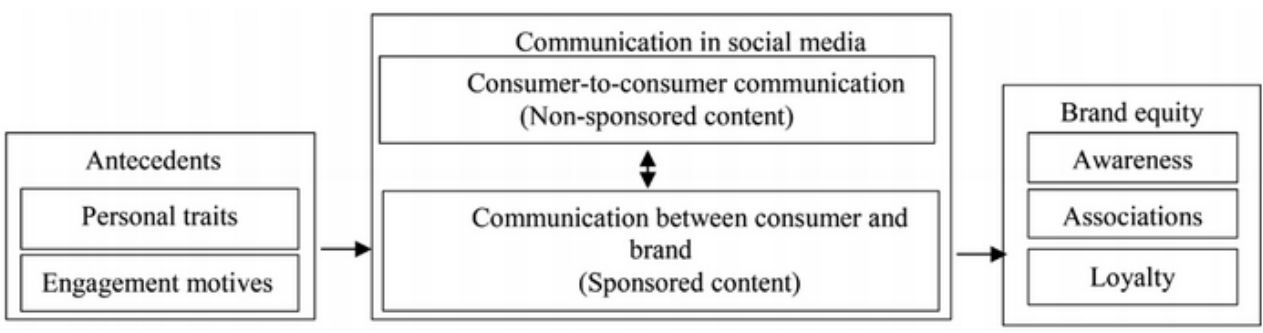

Source: Zailskaite-Jakse and Kuvykaite (2016

There is already some research regarding the influence of internet and its social media on consumer brand engagement. The most important is COBRA Theory, developed by Mutinga, Moorman and Smit (2011); this theory separates the activeness on social media use into three dimensions that demonstrate the path of involvement with band-related content. The categories are:

(1) "Consuming brand-related content": represents the consumers with a minimum level of online brandrelated activeness, as these people participate on social media but do not actively contribute or create content.
(2) "Contributing brand-related content": this category represents the middle level of activeness, in which the consumers sometimes interact about brands, making comments, posting pictures, videos or any other content.

(3) "Creating brand-related content": represents the consumers who actively produce and publish brandrelated content.

Table 2 illustrates all the types and some examples of social media uses of each one.

Table 2 - COBRA Typology

\begin{tabular}{|c|c|c|}
\hline & COBRA type & Examples of brand-related social media use \\
\hline \multirow{3}{*}{ 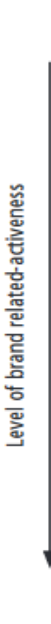 } & Consuming & $\begin{array}{l}\text { - Viewing brand-related video } \\
\text { - Listening to brand-related audio } \\
\text { - Watching brand-related pictures } \\
\text { - Following threads on online brand community forums } \\
\text { - Reading comments on brand profiles on social network sites } \\
\text { - Reading product reviews } \\
\text { - Playing branded online videogames } \\
\text { - Downloading branded widgets } \\
\text { - Sending branded virtual gifts/cards }\end{array}$ \\
\hline & Contributing & $\begin{array}{l}\text { - Rating products and/or brands } \\
\text { - Joining a brand profile on a social network site } \\
\text { - Engaging in branded conversations, e.g. on online brand community forums or } \\
\text { social network sites } \\
\text { - Commenting on brand-related weblogs, video, audio, pictures, etc. }\end{array}$ \\
\hline & Creating & $\begin{array}{l}\text { - Publishing a brand-related weblog } \\
\text { - Uploading brand-related video, audio, pictures or images } \\
\text { - Writing brand-related articles } \\
\text { - Writing product reviews }\end{array}$ \\
\hline
\end{tabular}

Source: Muntinga, Moorman and Smit (2011) 
Graffigna and Gambetti (2014) developed a model that highlights the features a brand has to have in order to trigger the development of an engage relationship with customers. In order to be viewed as a "life mate" - a humanization of the brand by customers, in other words, a lifelong companion - a brand has to meet some conditions. The first condition is to be a dream carrier, which happens when the brand is perceived as a source of imagination, of possible selves and possible worlds where the consumers' selves can be free to express themselves; also, the brand also has to sustain consumers' projections and expectations.

When this condition is complete, the brand is perceived by the customer as a friend (friendship phase), as an important component of consumer life and as source of positive feelings. The second condition is the brand as a relationship facilitator, which is the brand encouraging consumers' interpersonal network, helping them to get along with their connections and get in touch with people with shared passions and interests; also, the brand should make the consumer feel more self-confident. When the second condition is complete starts the intimacy phase in which there is the beginning of genuine engagement and the consumer perceives the brand as an important component of their daily life. The last condition is the brand as a compass and it happens when the brand becomes a reference point for consumers that is constantly present across time in their lives. When the last phase is complete there is the "symbiotic phase", which represents the highest level of engagement and the brand is seen as indispensable.

\section{Background from Brazil and Italy}

\section{Millennials}

In Brazil, the total number of millennials is 51 million (24.50\% of total population) (Innovar e Pesquisa, 2016). According to Visa (2017), millennials in Brazil is the group that buy the most through internet, holding more than $20 \%$ of all the transactions made online. As for their goals in life: $74 \%$ want to travel and get to know different places around the world; $43 \%$ expect to earn enough to maintain a comfortable life; $10 \%$ want to become rich (Innovar e Pesquisa, 2016). As for the Italian millennials, they are 11.2 Million (18.50\% of total population), and current 8.6 million of them are active in SM.
As a unique characteristic of the Italian Millennials is that the country has the highest percentage of unemployment among young people in Europe, being almost 38\% in 2017 for under-35 age bracket (Edwards, 2017).

Moreover, they are characterized by being pessimist about their future, they are usually unhappy, ignorant and have lack of self-confidence (Bianchi, 2016).

By 2016, 45\% of the Brazilian population was active in SM (approximately 93.6 million people). According to the same research, Brazilians are most active (in decreasing order) in FaceBook, YouTube, Instagram, Google+, Twitter, Linkedin, and Pinterest. In 2016, the country held the biggest number of social network users in Latina America (Canal Tech, 2016). Moreover, Brazil is the global leader in time spent on the internet by month, as each user spend in average 21 minutes by "visit" and 650 hours per month (O Globo, 2015).

By 2017 in Italy, 39 million of people have access to internet and 31 million actively use SM (out of a population of 60 million) (Nappi, 2017). According to the same research, Italians are most active (in decreasing order) in YouTube, Facebook, Instagram, Twitter, Google+, Linkedin, Pinterest, and Tumblr.

\section{Cultural dimensions}

Culture can have many definitions, however, the one adopted by this thesis is that culture, according to Engel, Blackwell and Miniard (1993), are the set of values, ideas, artifacts and other symbols that help individuals to communicate, evaluate and interpret as members of a society.

Even though the world suffered a wave of globalization, the cultural aspects of each society continued the same, thus people from different countries kept their own different habits, values, and norms (Zhu, Quan \& Xuan, 2006).

Moreover, according to Lynn, Zinkhan and Harris (1993), the cultural background is a key environmental characteristic that determines consumer behavior in a society. In order to analyze the national culture, the Hofstede's National Culture Framework was chosen for two reasons: (1) this is a widely use framework between scholars when developing research related to culture and (2) this framework analyze value-based factors that affects purchase decisions (Dimitrova, Kim \& Smith, 2017) 
what might lead to an impact on the interaction of the consumer with the brand.

Considering the cultural aspect developed by Geert Hofstede (2001) it is possible to observe some differences between Italy and Brazil. Hofstede (2001) characterize culture into six main dimensions:

- Power distance Index (PDI): this dimension is defined as the extent to which the people in the society accepts that power is unequally distributed. Also, as higher is the score on this dimension, more people will have need for power, wealth, prestige, and status. Hence, Brazil scored higher than Italy (which scored medium), showing that the first country is more likely to respect hierarchy and accept that power is distributed unequally.

- Uncertainty avoidance Index (UAI): this dimension measures the degree of tolerance for uncertainty. Regarding this, both countries scored high, meaning that both societies feel threatened by unknown situations.

- Individualism versus collectivism Index (IDV): this dimension is regarding the degree of collectivism within a society, it measures if people take decisions considering the whole group or just the individual perspective. On this dimension Italy scored high and Brazil low, which means that in Italy people are more independent than in Brazil (which is more collectivist).

- Masculinity versus Femininity Index (MAS): this dimension measures the degree which a culture has its social roles clearly distribute, valuing more male characteristics such as assertiveness, success, and competitiveness. If a culture scores low, it means that it has feminine characteristics, such as solidarity, modesty, and quality of life. In this dimension, Italy scored high and Brazil medium, showing that the Italian society is more masculine than Brazilian.

- Indulgence Index (IDL): this dimension is related to the degree in which people try to control their desires and impulses. Brazil scored high while Italy scored low, meaning that Brazilians are more indulgent, having weaker control over their desires and impulses than Italians.

- Long term versus short term orientation Index (LST): this dimension measures the degree in which a culture values traditions, being or more normative or more pragmatic. Italy scored high and Brazil medium, showing that Italy is more pragmatic than Brazil.

Figure 2 - Hofstede Dimensions - Brazil in comparison with Italy

\section{Brazil \\ in comparison with Italy}

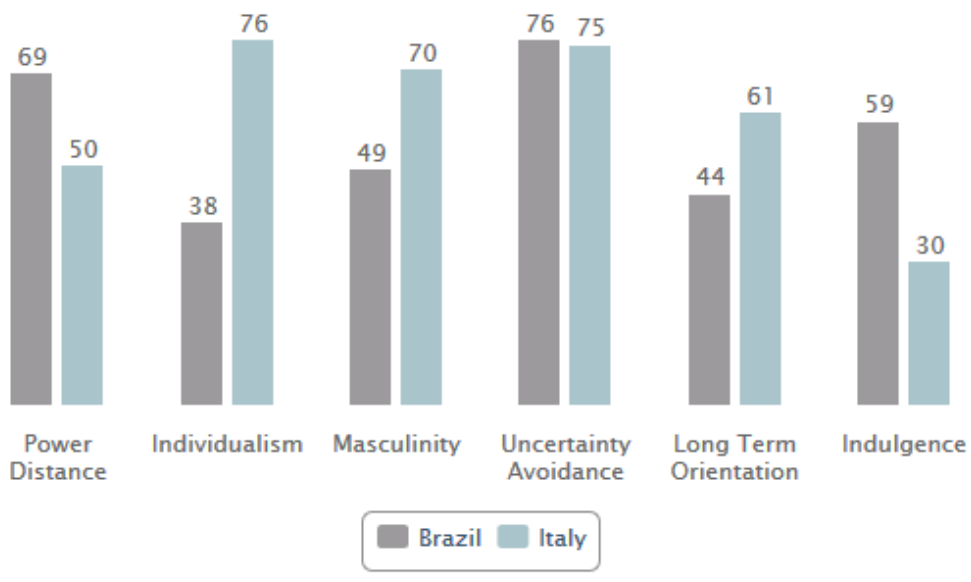

Source: Hofstede (2001)

\section{Hypothesis development}

According to Hofstede (2001), the nature and intensity of social media use can be shaped by cultural context. For instance, a studied conduct by Kim, Yeong and So (2011) showed that collectivist cultures tend to emphasize obtaining social support from existing social relationships, while individualistic cultures focus more on seeking entertainment on social media. 
The Millennials Luxury Brand Engagement on Social Media: A Comparative Study of Brazilians and Italians

\section{Power Distance}

A research developed by Kim and Zhang (2014) showed that there is a positive correlation between consumers from high PDI cultures and the purchase of luxury brands, as people from this type of culture seek wealth, prestige and status recognition. Hence, this constant need for status can lead to a higher volume of creating content online, as it could display to others one's individual achievements; the creation of posts with luxury brands products, such as purses, shoes and clothes, could show to others one's personal status and bring prestige in the format of likes and comments ( $\mathrm{H} 1 \mathrm{a})$.

Furthermore, people from this type of culture tend to admire and respect who has achieved a perceived high social status: for millennials, these people are the so-called digital influencers and bloggers. Brazilians Millennials probably are more influenced by these people on social media than Italians are, as they value the possibility of following these people, compare, admire and see how the daily lives of these "famous" people are ( $\mathrm{H} 1 \mathrm{~b})$.

H1a: Brazilian Millennials "create" more luxury brands posts on social media than Italians due to the Brazilian high level of power distance

H1b: Brazilian Millennials are more influenced by "digital influencers" and "bloggers" than Italians due to their high level of power distance

\section{Individualism versus Collectivism}

A research developed by Mourali, Laroche and Pons (2005) and Doran (2002) showed that consumers from collectivist cultures consult others and rely on collective brand perceptions in order to make a purchase, whilst individualistic consumers tend to prioritize their own experiences and expertise in purchase decisions.

In order to make a luxury brand purchase, Brazilians Millennials consumers would monitor more closely the brands they are interesting too, with the purpose of analyze more carefully the pages, read comments about it and so on. As consequence, they would follow more online brand pages in order to support their purchase decisions, therefore:

H2: Brazilian Millennials "follow" more luxury brands pages on social media than Italians due to the Brazilian high level of collectivism

\section{Long-term versus Short-term}

According to Goodrich and Mooji (2013), the crossing between the LST and the IDL explains which the main functions of SM are to a specific culture. In this regard, the research frames Brazil as a country that uses SM with the purpose of self-enhancement, self-disclosure, engage with people, make friends and have consumer-to-consumer related activities. On the other hand, for Italians, the use of social media is related to a limited personal interaction, as they have selective friends on their socials and prioritize the security of the information they are disclosing on those SM.

The study also emphasized that Brazilians, as short-term oriented country, has the tendency to be very image concerned and carefully when crafting their online persona: image and reputation are key aspects for their culture and it guides their online behavior. In this sense, it is possible to suggest that as a short-term oriented culture, Brazilians tend to share more posts with their friends on SM, with the purpose of self-enhancement: share the right content can help them to better define their online persona. Moreover, this is a complementary activity to the creation of content: the creation gives them the desired status and affirm their social position, whilst the sharing of content will enhance their displayed status and reaffirm the perception they want people to develop about them.

H3: Brazilian Millennials "share" more luxury brands posts on social media than Italians due to the Brazilian short-term view

In summarization, the hypothesis connects the Hofstede's theory with COBRA's model: the author intents to develop a model connecting both, as shown in the Figure 3 below. 
Figure 3 - Model Culture and Brand Engagement in Social Media

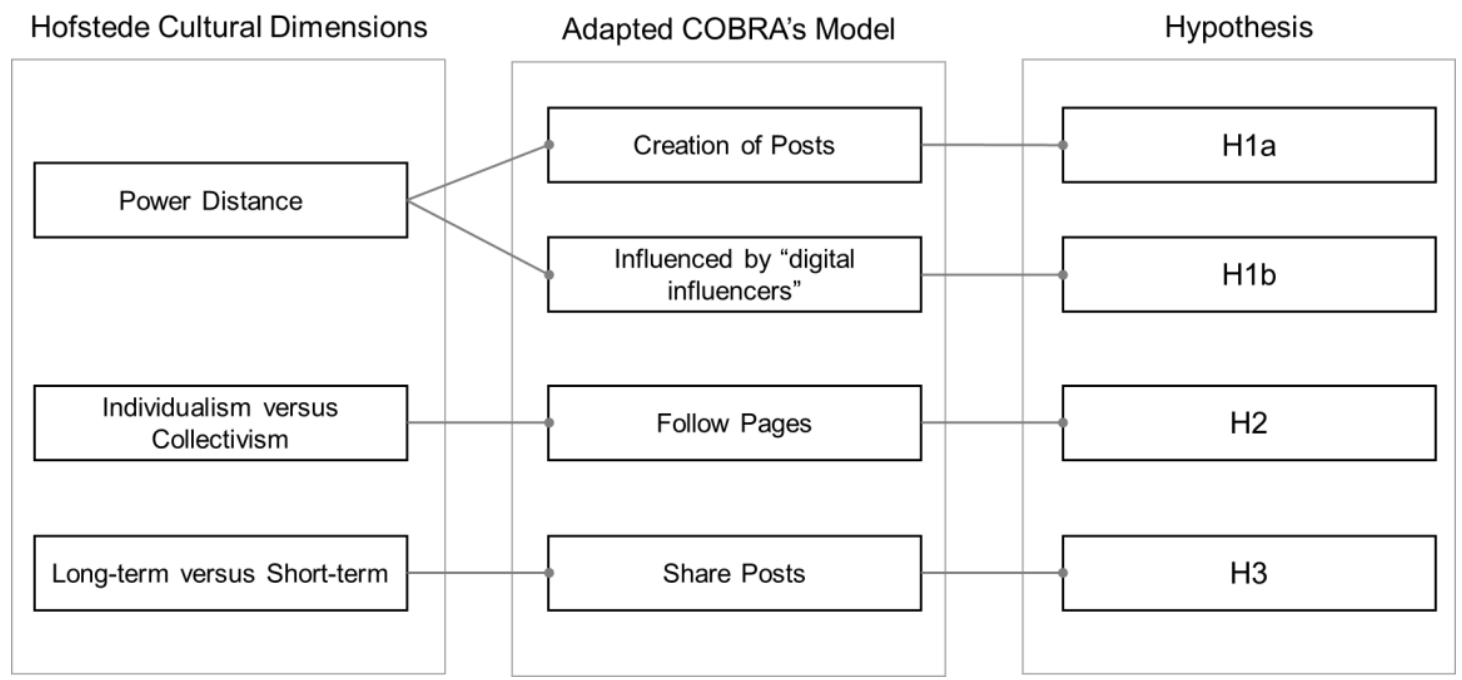

Source: Author's Development

\section{Methodology}

\section{Research Design}

The unit of analysis is the phenomenon of consumer engagement on social media. This study takes into consideration the Hofstede's cultural aspects of Brazil and Italy, comparing three luxury brands and the Brazilian and Italian CBE. The level of analysis is macro, considering Brazil and Italy and not taking into account the differences between States within the countries. Furthermore, the social media that are studied are considered as a unit in the conclusion and not separately.

\section{Brands}

The three brands chosen for this study are: Chanel, Louis Vuitton, and Prada. The choice was based on the definition of luxury brand, which is a brand that sells something expensive, high quality, hard to obtain, extravagant, and offers something more indulgent than a necessity (Corbellini \& Saviolo, 2009). If the brand it is present on both countries and if they sell a similar range of products, ranging from accessories (such as sunglasses, purses, bags, belts etc.) to clothes and shoes. The last requirement was the online presence on social media platforms, such as Facebook, Instagram, YouTube and Twitter.

\section{Chanel}

The brand Chanel was founded by the French designer Coco Chanel in 1910. The brand is famous for its timeless designs, trademark suits and black dresses. By 1920, Coco introduced her first perfume, a suit and the little black dress to her collection. Nowadays the company is privately held by Alain and Gerard Wertheimer, grandsons of Pierre Wertheimer (a business partner of (Coco).

\section{Louis Vuitton}

LV was founded in 1854 by Louis Vuitton in France with its iconic truck and, by that time, the LV's famous monogram already appeared on most of the products. The company opened its first store in 1885, at Oxford Street in London; and by 1900 the company was already considered global. Nowadays, Louis Vuitton is part of the Group LVMH.

\section{Prada}

Prada was founded in 1913 by Mario Prada in Milan, Italy. The first store was located at Galleria Vittorio Emanuele II, one of the most luxury galleries in the world. The company maintained its core business since the beginning, which is sell luggage, accessories and luxury goods produced with fine materials and by hand. The brand quickly became a sensation in the Italian Luxury market and by 1919 Prada received the warrant of "Official Supplier of the Italian Royal Household". Nowadays, Prada is part of Prada Group, which include many other luxury brands.

\section{Brands on Social Media}

Regarding the presence of the three brands on SM, Chanel and LV have a larger presence on Facebook than Prada, however, LV have a greater number of visits per follower than Chanel. On Instagram, Chanel is to brand with the larger number of followers, but with the smallest number of posts, 
The Millennials Luxury Brand Engagement on Social Media: A Comparative Study of Brazilians and Italians

whilst Prada has the smallest number of followers and the highest number of posts. On Twitter, Chanel has almost the double of followers than LV, while Prada has a considerable small number of followers.
YouTube seems to be the less used media, as none of the three brands has more than one million followers.

Table 3 - Brands on Social Media

\begin{tabular}{|c|c|c|c|}
\hline & Chanel & Louis Vuitton & Prada \\
\hline $\begin{array}{l}\text { Number of followers on } \\
\text { Facebook }\end{array}$ & 20.14 million & 20.25 million & 6.25 million \\
\hline $\begin{array}{l}\text { Number of total visits on the } \\
\text { Facebook Page }\end{array}$ & 152 thousand & 298 thousand & - \\
\hline Number of visit per follower & 0,008 & 0,015 & \\
\hline $\begin{array}{l}\text { Number of followers on } \\
\text { Instagram }\end{array}$ & 24.8 million & 19.8 million & 13.9 million \\
\hline $\begin{array}{l}\text { Number of posts on } \\
\text { Instagram }\end{array}$ & 878 & 2,281 & 2,956 \\
\hline $\begin{array}{l}\text { Number of followers on } \\
\text { Twitter }\end{array}$ & 13.4 million & 7 million & 901 thousand \\
\hline $\begin{array}{l}\text { Number of followers on } \\
\text { YouTube }\end{array}$ & 942 thousand & 170 thousand & 74 thousand \\
\hline $\begin{array}{l}\text { Number of videos on } \\
\text { YouTube }\end{array}$ & 671 & 290 & 264 \\
\hline
\end{tabular}

Source: Author's Development based on data from Facebook, Instagram, Twitter and YouTube

\section{Social Media}

Moreover, the four social medias chosen for the research are Facebook, Instagram, YouTube and Twitter. The choice was made based on the monthly visitors of each channel (on June 2017).

\section{Methods for gathering and analyzing data}

The research method design was based on the quantitative verification method, also referred as hypothesis-testing research (Newman \& Benz, 1998). Usually this type of research starts with a topic of interest, literature reviews, statement of theory or research question, from which some hypotheses are derived.

After, an experimental design is developed to measure the dependent variables - the consumer engagement in this case (Newman \& Benz, 1998).

\section{Data Collection}

The data collection was developed through a quantitative structured online survey on both countries in order to measure the consumer engagement regarding luxury brands. The quantitative method was chosen because it is the most effective method to test hypotheses (Newman \& Benz, 1998). The easiness and the advantage of the speed and vast networking (Olsen, 2012) also played a fundamental role when choosing the methodology.
Moreover, the study was design as a cross-sectional research, where the author aims to compare two samples at a single point of time.

Regarding the quantitative questionnaire, it was conducted in November 2017. First, it had an initial check of information in order to assure the respondent satisfy the conditions of being from Italy or Brazil, be a millennial, be brand-sensitive (consider the brand as a distinctive characteristic of product quality) and be a social media user. Then, there was a cultural question section, which aims to analyze if the respondent corresponds to Hofstede's cultural aspects (independent variables): this section was developed based on Hofstede's book Culture's Consequences (2001) and studies that aimed to analyze cultural dimensions; the author developed three questions for each tested dimension. Additionally, there were some questions regarding social media and, subsequently, 23 Likert constructs (ranging from 1 - Totally Agree to 5 - Totally Disagree) for each brand to address the consumer engagement level of the respondent. This section was developed based on Gambetti and Graffigna (2014) and COBRA's Framework, with some adaptations due to the development of new social medias, new technologies, and to properly reach the target group. The questionnaire was available in Italian and 
Portuguese and it were translated by native speakers from both countries.

The method to choose the sample was the snowball (a nonprobability sample) as this method was the most convenient and it was easier to gather responses from the target group. The questionnaires were sent through a unique link, and it was posted on Facebook groups, posted on Instagram by the author and sent by the author to all her network through text and email, both in Brazil and Italy. The use of social media and the author's network to send the questionnaires was due to the easiness to reach the target group: all her network are millennials and most of them users of social media. The number of questionnaires sent are not clear, as the author kindly asked for her network to spread the link, in order to gather the highest number of response from different type of people.

A total of 671 questionnaires were received, 341 from Brazil and 330 from Italy, however, some questionnaires were not taken into consideration as were not completed or because it did not correspond to the target group. In order to analyze the questionnaire, the first thing was to not consider answers from people who were not from either Brazil or Italy; then, the author excluded all the responses from people who were not millennials, who do not have social media and for last, those who do not perceived brand as a synonymy of quality. Thus, just 438 were valid ( 210 from Brazil and 228 from Italy). Regarding the demography of the respondents, in
Brazil, 51\% (107) of the respondent identify themselves with the feminine gender, while 49\% (103) as masculine. As for Italy, 42\% (96) respondents affirmed to be female, while 58\% (132) male.

\section{Data Analysis}

In order to analyze the data and answer the research question, authors used the software $R$ (version 3.5.0) and RStudio (version 1.1.453). A Generalized Additive Models for Location, Scale and Shape for each response variable and hypothesis.

Four models were developed. In each one, the objective was to verify the linear association between the response variables and the explanatory variable in linear multiple regression. The following control variables were used: country, age, gender, usage of Facebook, Instagram, Twitter, LinkedIn, YouTube, Pinterest, and Snapchat. Dummy variables to the countries were also introduced.

The control variables were initially selected by a variable selection model, Akaike Information Criterion (AIC). Afterwards, when some nonstatistically significant variables were left, they were discounted one by one to avoid spurious correlations.

\section{Results}

\section{Hypothesis 1a - Power Distance (PDI) and Creation Score}

The higher is the power distance higher is the content creation.

Figure 4-PDI score versus Creation score

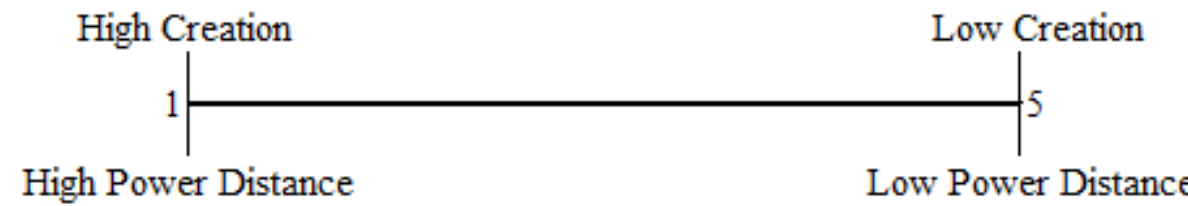

Source: Author's development (2018)

If 1 unit raise in the creation score leads to a reduction of -0.114 in the PDI score. Thus, the higher the creation score, the lower is the PDI score. Considering the control variables, it is possible to conclude that if the respondent uses Facebook, the PDI score raises 1,134. If the respondent uses LinkedIn, the PDI score raises 0.715, and if the respondent uses YouTube, the score decreases -0.349 . The average PDI score from the respondents that are born between 1980 and 1994 is lower than the average of the respondents that were born after 1994 (in average -0.877). There is no significative difference (with a 5\% level of significance) between the respondents born before 1980 and born after 1994 ( $p$-value $=0.203$ ). There is no evidence of heteroscedasticity (non-constant variance) or of dependence within the respondents' answers. 
The Millennials Luxury Brand Engagement on Social Media: A Comparative Study of Brazilians and Italians

Table 4 summarize the estimation, standard error, t-test and p-value for all variables.

Table 4 - Results: Hypothesis 1 a

\begin{tabular}{|l|c|c|c|c|}
\hline Variable & Estimation & Standard Error & T-test & P-value \\
\hline $\begin{array}{l}\text { Reference (Italians, born after } \\
1994 \text { and that do not use } \\
\begin{array}{l}\text { Facebook, LinkedIn, and } \\
\text { Youtube) }\end{array}\end{array}$ & 3.930 & 0.3982 & 9.87 & $<000.1$ \\
\hline Brazilian & $(-) 2.307$ & 0.1409 & $(-) 16.37$ & $<0.001$ \\
\hline Usage of Facebook & 1.134 & 0.3051 & 3.72 & $<0.001$ \\
\hline Usage of LinkedIn & 0.715 & 0.1446 & 4.94 & $<0.001$ \\
\hline Usage of Youtube & $(-) 0.349$ & 0.1326 & $(-) 2.64$ & 0.010 \\
\hline Born between 1980 and 1994 & $(-) 0.877$ & 0.1999 & $(-) 4.39$ & $<0.001$ \\
\hline Born before 1980 & 0.830 & 0.6482 & 1.28 & 0.203 \\
\hline Average of Creation Score & $(-) 0.114$ & 0.0567 & $(-) 2.01$ & 0.046 \\
\hline
\end{tabular}

Source: Author's development (2018)

In conclusion, Hypothesis 1 a was rejected since we found that the higher the power distance acceptance, the lower will be the creation of online posts.

\section{Hypothesis 1b - Power Distance (PDI) and Inspiration Score}

The higher the score, the lower is the power distance and the lower the score, the higher the person is inspired by a digital influencer.

Figure 5 - PDI score versus Inspiration score

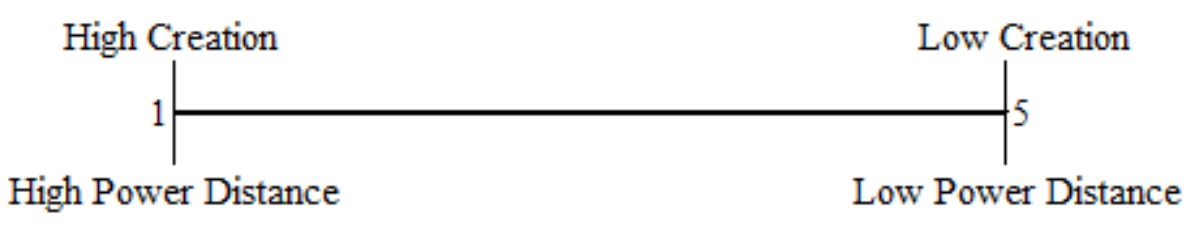

Source: Author's development (2018)

The reference estimation (3.144) is concern to the average score of PDI from Italian users who does not have a Linkedln account, and inspired by digital influencers.

Model showed that there is a relationship with $5 \%$ of significance between the average of PDI and the inspiration by digital influencers. When the respondent does not feel inspired by digital influencers, the PDI grows by 0.167 in the score. If a person is from a group that has a higher acceptance of unequal power distribution within it, the higher is the chances that people inside that group will be inspired by digital influencers.
Moreover, considering the control variables, it is possible to conclude that if the respondent uses LinkedIn, the PDI score will raise 0.175 .

If the respondent is Brazilians, the average PDI score is -1.401 lower than an Italian, considering everything else constant.

In this analysis, 438 observations were considered, and the quantile residual analysis indicates the error has a normal distribution. There is no evidence of heteroscedasticity (non-constant variance) or of dependence within the respondents' answers.

Table 5 summarize the estimation, standard error, t-test and p-value for all variables. 
Table 5 - Results: Hypothesis $1 \mathrm{~b}$

\begin{tabular}{|l|c|c|c|c|}
\hline Variable & Estimation & Standard Error & T-test & P-value \\
\hline $\begin{array}{l}\text { Reference (Italians, without a } \\
\text { LinkedIn account and } \\
\text { inspired by digital influencers) }\end{array}$ & 3.114 & 0.1149 & 27.11 & $<000.1$ \\
\hline B razilian & $(-) 1.401$ & 0.1033 & $(-) 13.57$ & $<0.001$ \\
\hline U sage of LinkedIn & 0.175 & 0.0766 & 2.28 & 0.023 \\
\hline Inspired by digital infuencers & 0.167 & 0.0740 & 2.26 & 0.024 \\
\hline
\end{tabular}

Source: Author's development (2018)

In conclusion, Hypothesis $1 \mathrm{~b}$ is accepted, as respondents with higher power distance (considering Hofstede's score), feel inspired by digital influencers while respondents with lower power distance does not feel the same.
Hypothesis 2 - Individualism versus Collectivism (IDV) and Follow score
The higher is the IDV score, the lower is the is the consumption of online content.

Figure 6-IDV score versus Follow score

High Consumption<smiles>C1CC2(C1)CC2</smiles>

Collectivism
Low Consumption<smiles>[SiH3]</smiles>

Individualism

Source: Author's development (2018)

The model shows that there is a negative association relationship ( $5 \%$ of significance) between IDV score and the Follow score. A raise of 1 unit in the follow score leads to a reduction of -0.144 in the IDV Score. The lower the consumption of online content, the higher is the degree of collectivism in the group. Regarding the control variables, if the respondent uses Instagram, the IDV score raises 1.501 and if the respondent uses Pinterest, the IDV score raises 0.296, showing that, the more individualist is the group, the higher is the usage of these social medias.

However, if the respondent is Brazilian, the IDV score decreases -1.441 , considering everything else constant, meaning that the country is more collectivist than the reference (Italy).

Table 6 summarize the estimation, standard error, t-test and p-value for all variables.

Table 6 - Results: Hypothesis 2

\begin{tabular}{|l|c|c|c|c|}
\hline Variable & Es timation & Standard Error & T-test & P-value \\
\hline $\begin{array}{l}\text { Reference (Italian respondents } \\
\text { that does not use Instagram or } \\
\text { Pinterest) }\end{array}$ & 3.191 & 0.3509 & 9.10 & $<000.1$ \\
\hline Brazilian & $(-) 1.441$ & 0.1487 & $(-) 9.69$ & $<0.001$ \\
\hline U sage of Instagram & 1.051 & 0.3177 & 3.31 & 000.1 \\
\hline U sage of Pinterest & 0.296 & 0.1455 & 2.04 & 0.044 \\
\hline A verage of Consume Score & $(-) 0.144$ & 0.0581 & $(-) 2.78$ & 0.006 \\
\hline
\end{tabular}

Source: Author's development (2018) 
In conclusion, Hypothesis 2 was rejected, as the degree of collectivism in the group. lower is following pages the higher is the

Hypothesis 3 - Long-term versus Short-term score (LTS) and Share Score

If the LTS score is high, the lower is the average contribution of the user

Figure 7 - LTS score versus Share score

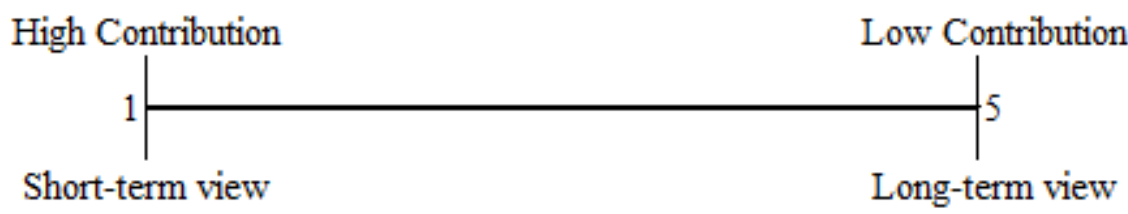

Source: Author's development (2018)

A raise of 1 unit in the Share score, leads to a raise of 0.089 in the LTS score. Even though it is a small raise, it is still significative. This means that the lower the contribution, the higher is the long-term view of the respondent. Taking into consideration the control variables, if the respondent uses Facebook, the average LTS score raises 3.287, if she or he uses Twitter, the score raises 0.289 , and if the respondent uses Linkedln, the score increases 0.153.

Table 7 summarize the estimation, standard error, t-test and $p$-value for all variables.

Table 7 - Results: Hypothesis 3

\begin{tabular}{|l|c|c|c|c|}
\hline Variable & Estimation & Standard Error & T-test & P-value \\
\hline $\begin{array}{l}\text { Reference (Italians users that } \\
\text { do not use Facebook, Twitter } \\
\text { or LinkedIn) }\end{array}$ & 0.821 & 0.0529 & 15.52 & $<000.1$ \\
\hline B razil & $(-) 2.874$ & 0.0537 & $(-) 53.54$ & $<0.001$ \\
\hline Usage of Facebook & 3.287 & 0.0604 & 54.42 & $<0.001$ \\
\hline U sage of Twitter & 0.289 & 0.0444 & 6.51 & $<0.001$ \\
\hline U sage of LinkedIn & 0.153 & 0.0516 & 2.97 & 0.004 \\
\hline A verage of Share Score & 0.089 & 0.0147 & 6.03 & $<0.001$ \\
\hline
\end{tabular}

Source: Author's development (2018)

In conclusion, Hypothesis 3 was accepted, as this means that the higher the contribution, the higher is the short-term view of the respondent.

\section{Conclusions}

This research aimed to find if national culture affects the consumer brand engagement on luxury brands on social media among millennials from Brazil and Italy, using Hofstede's cultural dimensions and COBRA's framework.

We rejected Hypothesis $1 \mathrm{a}$ while Hypothesis $1 \mathrm{~b}$ was accepted. Power Distance showed a negative relationship with creation of posts, meaning that the higher the Power Distance inside a group, the lower will be the creation of posts. Moreover, if the respondent uses Facebook and/or Linkedln, the Power Distance Index is lower, while if the respondent uses YouTube, the Power Distance Index is higher. Interestingly, Facebook and Linkedln are social medias that aim the interaction between people, while YouTube is a social media that aims to show videos made by other users. Companies should use YouTube to advertise in Brazil, while use Facebook and Linkedln in Italy. We interpret that Facebook and Linkedin are perceived as horizontal medias, on other words, sharing among equals. Since Italy is less hierarchical than Brazil they are more willing to show luxury brand relationship than Brazilians. 
Regarding Hypothesis $1 \mathrm{~b}$, the model shows that the higher the Power Distance Index, the higher is the chance of this person feel inspired by digital influencers. Since Brazil has a higher PDI, luxury companies could exploit this characteristic and use more of digital influencers to advertise their products in the country. On the other hand, as Italians feel less inspired by these people, luxury companies should decrease their marketing efforts with digital influencers.

As for Hypothesis 2, IDV had a negative relationship with following pages (the consumption of content online), thus, the higher the degree of collectivism in the country, the lower will be the following pages. One possible explanation is that in a collectivist society like Brasil millennials are more prone to follow digital influencers than regular people connection with luxury brand. Furthermore, if the respondent uses Instagram and/or Pinterest, her or his level of individualism increases, showing that the more individualistic the person, the higher is the usage of these social medias.

As for Hypothesis 3, there is a relationship between LTS and sharing posts, as the shorter the view, the higher is the degree of sharing posts online. Short term cultures are also associated that are prepotent, that are very proud about their own achievement while long term cultures tend to value humility. Therefore, in a short term culture like Brazil millennials are more prone to show their relationship with luxury brand than Italians as a sign of their own achievements. This study deepens the understanding of the relationship of brand engagement and national cultures particularly on social media platforms. We have shown that indeed millennials of Brazil and Italy are impacted differently in different platforms.

\section{REFERENCES}

Alsop, R. (2008). The Trophy Kids Grow Up. San Francisco: Jossey-Bass.

Bianchi, A. (2016). I Millennial italiani in cinque punti. Retrieved from http://www.ninjamarketing.it/2016/09/29/i-millennialitaliani-in-5-punti/

Boyd, D. M. \& Ellison, N. B. (2008). Social network sites: definition, history, and scholarship. I Comput Mediat Commun, 13(1), 210-230.

Bowden, J. L. (2009). The process of customer engagement: a conceptual framework. Journal of Marketing Theory and Practice, 17(1), 63-74.
Furthermore, national culture is relevant in setting online marketing campaigns. Management contributions of this study are also straightforward, Brazilians millennials are deeply influenced by digital influencers. They are willing to consume and engage with the life style of a famous online person. At the same time, if they are able to consume they like to show to other people what they have. On the other hand, regular people are less able to influence other people's behavior online. Luxury brands in Brazil should largely work with digital influencers at the same time that they should create opportunities to consumers share their own experiences with brands.

As for limitations of this research we researched only two countries and three luxury brands, leaving space for further investigation in different cultures and different brands. Furthermore, regarding Hofstede's model that was used in this study, even though it is a widely used model for cultural-related studies, the research was developed in the 1980s and it might be considered as "outdated" by some scholars. Moreover, we used a non-probabilistic sample of millennials in both countries. This study leaves an opportunity for further investigation: a qualitative study and an experimental research both on the cultural side and brand engagement might lead to a better understand of the relationship between culture and CBE. The relationships between LTS, IDV and PDI with social medias are yet not clear and it could be better understood with more focused studies. Moreover, another study related to the consumer engagement on luxury brands would be interested in order to better understand online behavior.

Canal Tech (2016). Brasil é o país que mais usa redes sociais na América Latina. Retrieved from https://canaltech.com.br/redes-sociais/brasil-e-o-paisque-mais-usa-redes-sociais-na-america-latina-70313/

Dimitrova, B., Kim, S. \& Smith, B. (2017). Does host country culture affect foreign retailer performance?. Marketing Journal, 1, 5-20.

Doran, K. B. (2002). Lessons learned in cross-cultural research of Chinese and North American consumers. Journal of Business Research, 55(1), 823-829.

Edwards, C. (2017). Italy has EU's highest level of youth unemployment, study shows. Retrieved from https://www.thelocal.it/20170718/italy-european- 
The Millennials Luxury Brand Engagement on Social Media: A Comparative Study of Brazilians and Italians

union-most-highest-percentage-neet-unemployedyoung-people-millennials

Engel, J. F., Blackwell, R. D. \& Miniard, P. W. (1993). Consumer Behavior. United States of America: The Dryden Press.

Fournier, S. \& Avery, J. (2011). The uninvited Brand. Business Horizons, 54(3), 193-207.

Fromm, J. \& Garton, C. (2013). Marketing to Millennials: reach the largest and most influential generation of consumers ever. Barkley: American Management Association.

Gambetti, R. C. \& Graffigna, G. (2010). The Concept of Engagement: A Systematic Analysis of the Ongoing Marketing Debate. International Journal of Market Research, 52(6), 801-826.

Gambetti, R. C. \& Graffigna, G. (2014). Grounding Consumer-brand Engagement: a Field-driven Conceptualization. International Journal of Market Research, 57(4), 605-629.

Goodrich, K. \& Mooij, M. (2013). How social are social media? A cross-cultural comparison of online and offline purchase decisions influences. Tandf Online, 20(1), $103-116$.

Hofstede, G. (2001). Culture's Consequences: Comparing Values, Behaviors, Institutions, \& Organizations Across Nations. Thousand Oaks CA: Sage Publications.

Hollebeek, L. D. (2011). Exploring Customer Brand Engagement: Definition and Themes. Journal of Strategic Marketing, 19(7), 555-573.

Hollebeek, L. D., Glynn, M. S. \& Brodie, R. J. (2014). Consumer Brand Engagement in Social Media: Conceptualization, Scale Development and Validation. Journal of Interactive Marketing, 28, 149-165.

Innovar e Pesquisa (2016). Geraçao Y: quem são e o que querem os millennials?. Retrieved from http://www.innovarepesquisa.com.br/en/blog/geracao -y-quem-sao-e-o-que-querem-os-millennials/

Killian, T., Hennngs, N. \& Langer, S. (2012). Do Millennials read books or blogs?. Journal of Consumer Marketing, 29(2), 114-124.

Kim, A. \& Ko, E. (2010). Impacts of Luxury Fashion Brand's Social Media Marketing on Customers Relationship and Purchase Intention. Journal of Global Fashion Market, 1(3), 164-171.

Kim, Y. \& Zhang, Y. (2014). The impact of powerdistance belief of consumers' preferences for status brands. Journal of Global Marketing, 27(1), 13-29.
Kim, W., Yeong, O. \& So, J., (2011). The dark side of the internet: attacks, costs, and responses. Information systems, 36(3), 675-705.

Kozinets, R. V. (2001). E-Tribalized Marketing? The Strategic Implications of Virtual Communities of Consumption. Journal of Marketing, 17(3), 1-22.

Kujur, F. \& Singh, S. (2015). Engaging customers through online participation in social networking sites. Asia Pacific Management Review, 22, 16-24.

Li, C. \& Bernoff, J. (2011). Groundswell: Winning in a World Transformed by Social Technologies. United States of America: Harvard Business Review.

Lujja, A. \& Ozata, F. Z. (2007). The consequences of consumer engagement in social networking sites. Business and Economics Research Journal, 8(2), 275291.

Lynn, M. Zinkhan, G. M. \& Harris, J., (1993). Consumer tipping: a cross-country study. Journal of Consumer Research, 20(3), 478-488.

Martin, C., \& Turley, L. (1994). Malls and consumption motivation: an exploratory examination of older Generation Y consumers. International Journal of Retail and Distribution Management, 32(19), 464-475.

Market Strategies (2014). Market Strategies Study: Millennial Shoppers Trust Social Media More but Diversify Beyond Facebook. Retrieved from http://www.marketstrategies.com/news/2380/1/Mark et-Strategies-Study--Millennial-Shoppers-Trust-SocialMedia-More-but-Diversify-Beyond-Facebook.aspx

Mourali, M., Laroche, M. \& Pons, F. (2005). Individualistic orientation and consumer susceptibility to interpersonal influence. Journal of Services Marketing, 19(3), 164-173.

Muntinga, D. G., Moorman, M. \& Smit, E. G. (2011). Introducing COBRAs: Exploring Motivations for BrandRelated Social Media Use. International Journal of Advertising, 30(1), 13-46.

Nappi, T. (2017). In Italia 31 milioni di utenti sono attivi sui social, 28 milioni da mobile. Retrieved from http://www.engage.it/ricerche/italia-31-milioni-utentiattivi-sui-social-28-milioni-mobile/96562

Newton, I. \& Benz, C. R. (1998). QualitativeQuantitative research methodology: exploring the interactive continuum. Illinois: Southen Illinois University Press.

O Globo (2015). Brasileiros gastam 650 horas por mês em redes sociais. Retrieved from http://blogs.oglobo.globo.com/nas- 
redes/post/brasileiros-gastam-650-horas-por-mes-emredes-sociais-567026.html

Olsen, W. (2012). Data Collection: key debates and methods in social research. Thousand Oaks: SAGE Publications.

Pate, S., \& Adam, M. (2013). The influence of social networking site on buying behaviors of millennials. Atlantic Marketing Journal, 2(1), 7.

Raines, C. (2003). Connecting Generations: The Sourcebook for a New Workplace. Berkeley: Crisp Publications.

Schivinski, B., Christodoulides, G. \& Dabrowski, D. (2016). Measuring Consumers' Engagement with BandRelated Social-Media Content: Development and Validation of a Scale that Identifies Levels of SocialMedia Engagement with Brands. Journal of Advertising Research, 56(1), 64-80.

Schultz, D. E. \& Peltier, J. (2013). Social Media's Slippery Slope: Challenges, Opportunities, and Future Research Directions. Journal of Research in Interactive Marketing, 7(2), 86-89.

Senecal, S., \& Nantel, J. (2004). The influence of online product recommendations on consumers' online choices. Journal of Retailing, 80(2), 159-169.

Smith, K. (2011). Digital marketing strategies that millennials find appealing, motivating, or just annoying. Journal of Strategic marketing, 19(6), 489-499.
Smith, K. (2012). Longitudinal study of digital marketing strategies targeting millennials. Journal of Consumer Marketing, 29(2), 86-92.

Sweeney, R. (2005). Reiventing Library Buildings and Service for the Millennial Generation. Journal of Library Administration and Management Association, 19(4), 165-175.

USC Dornsife (2017). Psychology of successfully marketing to millennials. Retrieved from http://appliedpsychologydegree.usc.edu/resources/inf ographics/psychology-of-successfully-marketing-tomillennials/

Visa (2017). Comportamento de consumo dos Millennials. Retrieved from https://www.visa.com.br/dam/VCOM/regional/lac/bra zil/media-kits/documents/infografico-consumomillennials-1.pdf

Zhu, M., Quan, R. \& Xuan, K. (2006). The impact of Sino-western cultural differences on IT products consumption. Journal of Technology Management in China, 1(2), 159-173.

Zailskaite-Jakse, L. \& Kuvykaite, R. (2016). Conceptualizing the social media communication impact on consumer based brand equity. Trendy Economics and Management, 25(2), 68-74

\section{SOBRE OS AUTORES}

- Melissa Akemi Casagrande Yamawaki Master in International Management at Università Commerciale Luigi Bocconi, Milan, (Italy). E-mail: melissakemi@gmail.com Orcid id: http://orcid.org/0000-0003$\underline{0290-0312}$

- Gilberto Sarfati PhD in Science Policy at University of São Paulo - USP, (Brazil). E-mail: gilberto.sarfati@fgv.br Orcid id: http://orcid.org/0000-0003-0772-5197 


\title{
O ENGAJAMENTO DOS MILENIALLS COM AS MARCA DE LUXO NAS MÍDIAS SOCIAIS: UM ESTUDO COMPARATIVO DE BRASILEIROS E ITALIANOS
}

\author{
Melissa Akemi Casagrande Yamawaki e Gilberto Sarfati \\ Universidade de São Paulo - São Paulo, (Brasil) \\ Università Commerciale Luigi Bocconi, Milão, (Itália)
}

\begin{tabular}{l}
\hline DETALHES DO ARTIGO \\
\hline Histórico do Artigo: \\
Recebido: 31 de janeiro de 2018 \\
Aceito: 08 de junho de 2018 \\
Disponível online: 22 de nov. de 2018 \\
Sistema de revisão "Double blind review" \\
Editor Científico \\
llan Avrichir
\end{tabular}

\section{Palavras-chaves:}

Engajamento do Consumidor

Marcas de Luxo

Mídia social

Cultura

Millennials

\begin{abstract}
RESUMO
Nas últimas décadas, as mídias sociais tornaram-se uma das atividades on-line mais populares entre os consumidores em todo o mundo, levando as empresas a se adaptarem e evoluírem suas estratégias para engajar o consumidor por meio de novas mídias. Considerando o ambiente on-line, a mídia social tem uma participação fundamental na construção do engajamento da marca do consumidor. Os consumidores podem desenvolver três funções nesta situação: consumidor, colaborador ou criador de conteúdo. Este estudo empírico visa compreender e comparar o engajamento dos consumidores da geração milênio, os millennials do Brasil e da Itália com marcas de luxo nas mídias sociais. As marcas de luxo escolhidas são Louis Vuitton, Chanel e Prada e as mídias sociais são Facebook, Twitter, YouTube e Instagram. O estudo utilizou um desenho de pesquisa quantitativa, com uma pesquisa por questionário baseada no framework COBRA e no modelo de Hofstede. Coletamos 438 respostas válidas. Os resultados sugerem uma relação entre cultura e engajamento do consumidor em marcas de luxo através de mídias sociais entre millennials do Brasil e da Itália.
\end{abstract}

C 2018 Internext | ESPM. Todos os direitos reservados!

\section{Para citar este artigo:}

Casagrande Yamawaki, M., \& Sarfati, G. (2019). The Millennials Luxury Brand Engagement on Social Media: A Comparative Study of Brazilians and Italians. Revista Eletrônica de Negócios Internacionais, 14(1), 14-30. doi:https://doi.org/10.18568/1980-4865.00\%p 